\title{
Clinicopathological Characteristics of Chordoma: An Institutional Experience and a Review of the Literature
}

\author{
Kordomanın Klinikopatolojik Özellikleri: Bir Kurum Deneyimi ve \\ Literatür Derlemesi
}

\author{
Rumana MAKHDOOMI, Altaf RAMZAN, Nayil KHURSHEED, Salma BHAT, Khalil BABA, Rasool MOHSIN, \\ Mubeen BASHARAT, Bhat YAMEEN, Rayees AHMAD, Lone IQBAL, Mohammad MAQBOOL, Hakeem AJAZ, \\ Mustafa FARHAT
}

Skims, Department of Pathology, Srinagar, Kashmir, India

Corresponding Author: Rumana MAKHDOOMI / E-mail: rumanahamid@rediffmail.com

\begin{abstract}
AIM: To study the clinicopathologic characteristics of chordomas from a single institution.

MATERIAL and METHODS: This study is a retrospective analysis of 18 cases of chordomas diagnosed over a period of 5-years at Sher-i-Kashmir Institute of Medical Sciences, Srinagar, from 2006 to 2010.

RESULTS: The overall mean age of the patients was 46.72 years. Males outnumbered females. Sacrum was the commonest site involved. Histopathologically, the majority of cases were conventional chordoma with four cases of chondroid variety. There was a single case of dedifferentiated chordoma that presented with bone metastasis. Most patients did well after surgery and radiotherapy. One patient had a local recurrence and one patient with dedifferentiated variant died on follow-up.
\end{abstract}

CONCLUSION: Though locally aggressive, chordomas are effectively treated with resection and postoperative radiotherapy.

KEYWORDS: Chordoma, Clivus, Sacrum, Chondroid chordoma, Dedifferentiated chordoma

öz

AMAÇ: Tek bir kuruluştan kordomaların klinikopatolojik özelliklerini incelemek.

YÖNTEM ve GEREÇLER: Bu çalışma, 2006 ile 2010 yılları arasındaki 5 yıllık bir dönemde Srinagar'daki Sher-i-Kashmir Tıp Bilimleri Enstitüsünde tanı konmuş 18 kordoma olgusunun retrospektif bir analizidir.

BULGULAR: Hastaların ortalama yaşı 46,72 yıldı. Erkeklerin sayısı kadınlardan fazlaydı. En sık tutulan bölge sakrumdu. Histopatolojik olarak olguların çoğu konvansiyonel kordomayken kondroid tipte dört olgu vardı. Kemik metastazıyla gelen tek bir dediferansiye kordoma olgusu görüldü. Çoğu hasta cerrahi ve radyoterapiye iyi sonuç verdi. Bir hastada yerel nüks oldu ve dediferansiye varyantın bulunduğu bir hasta da takip sırasında öldü.

SONUÇ: Lokal olarak agresif olmalarına rağmen kordomalar rejeksiyon ve postoperatif radyoterapiyle etkin bir şekilde tedavi edilebilir.

ANAHTAR SÖZCÜKLER: Kordoma, Klivus, Sakrum, Kondroid kordoma, Dediferansiye kordoma

\section{INTRODUCTION}

Chordoma is a rare, primary bone tumor arising from primitive notochord remnants of the axial skeleton. It accounts for $1-4 \%$ of all primary skeletal tumors $(15,8)$. The sacrum represents the most common anatomical site of origin accounting for $50-60 \%$ of all cases followed by the skull base region (25-35\%), the cervical vertebrae (10\%) and the thoracolumbar vertebrae (5\%). Chordomas show a dual epithelial and mesenchymal differentiation (19). Histopathologically, chordomas may show a 'typical/classical' morphology, a 'chondroid' morphology showing large islands of hyaline cartilage with areas showing classical morphology and a 'dedifferentiated' morphology showing sarcomatous areas interspersed with areas of classical chordoma (24). The biological behavior of chordomas is characterized by a generally slow aggressive local growth with a low to late tendency in metastasizing to distant sites including the lung, bone, soft tissue, lymph nodes, liver and skin (19). Up to $40-60 \%$ of patients develop distant metastases over the course of their disease (14). Surgery remains the cornerstone of chordoma treatment (11). Complete radical resection is however difficult because by the time the symptoms appear the tumor is so large that complete excision is frequently impossible (18). Thus despite its low-grade malignancy, chordoma has a low long-term local control rate 
$(25,7)$. The importance of radiation therapy, however, has increased over time in the treatment of local recurrent disease (6). We hereby analyze 18 cases of chordoma and discuss their clinicopathological characteristics and their outcome.

\section{PATIENTS and METHODS}

A retrospective analysis of all the cases of chordoma diagnosed in the department of Pathology at Sher-i-Kashmir Institute of Medical Sciences from January 2006 to December 2011 was done. This institute is a 650-bed tertiary care hospital in Kashmir which caters to the entire population of Kashmir valley, India. The clinical details of the patients were abstracted from the case records and relevant slides and blocks of the cases were retrieved and reviewed by a single pathologist. Fresh slides and sections were cut and wherever needed, special stains, i.e. PAS (periodic acid Schiff) with/ without diastase, were used. Immunohistochemistry (IHC) was used for confirmation of diagnosis.

\section{RESULTS}

\section{Demographic and Clinical Profile}

The overall mean age of the patients was 46.72 years (range 14-60 years). Females presented at a younger mean age (40.25 years) than males (48.57 years). Male: female ratio was 14:4. The commonest symptom was low back pain, it was seen in all patients with lumbosacral chordomas $(n=15)$. Radiculopathy was noticed in 5/18 (27.77\%) patients, constipation in $4 / 18(22.22 \%)$ and urinary symptoms in $2 / 18$ (11\%). Other symptoms seen were diplopia (11\%), palpable swelling (11\%) and quadriparesis (5.5\%) (Table I). The average duration of symptoms was 11.8 weeks (range 2-24 weeks). There was no gender difference in the duration of symptoms $(p>0.05)$.

\section{Imaging}

MRI was available in all the cases and CT scan in 16 cases.
Calcification on CT scan was noted in 50\% cases. MRI showed most of the lesions to be hypointense on T1- and hyperintense on T2-weighted sequences. Preoperative impression of chordoma was made on imaging in most of the cases however, in few patients other possibilities viz. metastasis, chondrosarcoma, schwannoma and lymphoma were also thought of. Imaging revealed involvement of sacrum in $61 \%(11 / 18)$, sacrococcygeal region in $11 \%(2 / 18)$, clivus in $11 \%(2 / 18)$, lumbosacral region in $5.5 \%(1 / 18)$, lumbar spine in $5.5 \%(1 / 18)$ and upper cervical region in $5.5 \%(1 / 18)$ of patients (Figure $1 \mathrm{~A}-\mathrm{C}$ ).

\section{Surgery}

All the patients underwent surgery. Total excision of the tumor along with resection of the lower sacrum ( 33 and below) was possible in 6 patients as there was no involvement of S2 or above. Other 9 patients of sacral chordomas were subjected to subtotal excision of the tumor because of widespread involvement of the surrounding tissues by the tumor. Two patients of clival chordoma underwent presigmoid subtemporal approach and subtotal excision of the tumor. One patient of C1-C3 tumor was managed by trans-oral decompression of the tumor with $2^{\text {nd }}$ stage occipito-cervical contour rod fixation.

\section{Histopathological/Cytological Characteristics}

Fine needle aspiration cytology was done in 2 patients of sacral chordomas preoperatively who had palpable tumor masses and in both cases abundant mucinous matrix with physalipharous cells were seen and a diagnosis of chordoma was suggested which was later confirmed on histopathology. Crush biopsy was done in 16 cases of chordoma, of which the diagnosis of chordoma was given in 15 cases. In one case of clival chordoma, the material was non-crushable. The histopathology in most cases showed classical morphology of
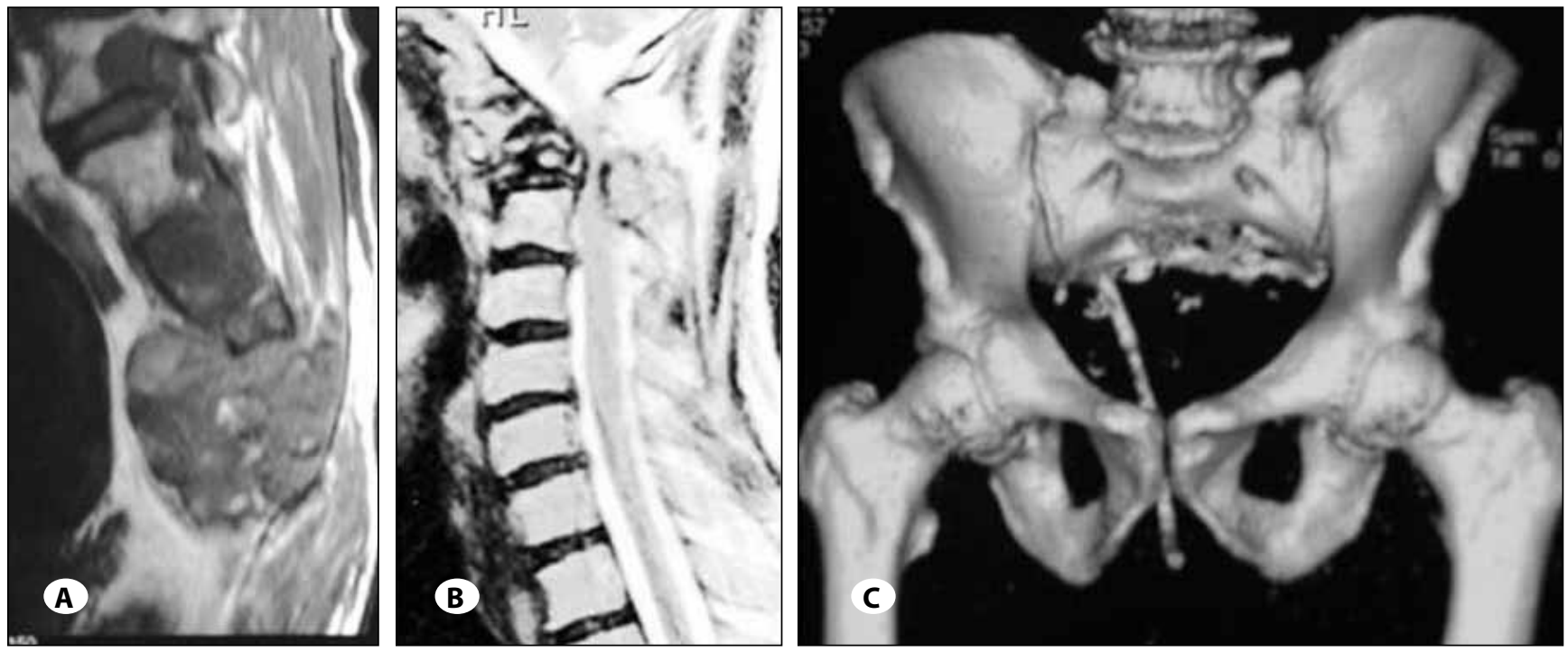

Figure 1: Imaging shows sacrococcygeal chordoma (A), chordoma involving the craniovertebral junction (B) and post-tumor resection CT scan of the sacrum and pelvis (C). 
Table I: Demographic and Clinical Profile of Patients

\begin{tabular}{|c|c|c|c|c|c|}
\hline $\begin{array}{l}\text { Case } \\
\text { No. }\end{array}$ & $\begin{array}{l}\text { Age/ } \\
\text { gender }\end{array}$ & $\begin{array}{l}\text { Site of } \\
\text { lesion }\end{array}$ & Symptomatology & Histopathology & Follow up \\
\hline 1 & $40 / \mathrm{M}$ & Clivus & Diplopia (2 weeks) & $\begin{array}{l}\text { Chondroid } \\
\text { chordoma }\end{array}$ & $\begin{array}{l}\text { EBRT } 20 \text { cycles RT, } 6 \text { years } \\
\text { on follow up }\end{array}$ \\
\hline 2 & $40 / \mathrm{M}$ & $\mathrm{C} 1-\mathrm{C} 3$ & $\begin{array}{l}\text { Spastic quadriparesis } \\
\text { ( } 2 \text { months) }\end{array}$ & Conventional Chordoma & $\begin{array}{l}\text { EBRT } 20 \text { cycles RT, } 6 \text { years } \\
\text { on follow up }\end{array}$ \\
\hline 3 & $35 / M$ & Sacral & $\begin{array}{l}\text { Low back ache, radiculopathy, } \\
\text { constipation ( } 2 \text { months) }\end{array}$ & Conventional Chordoma & $\begin{array}{l}\text { EBRT } 20 \text { cycles RT, } 5 \text { years } \\
\text { on follow up }\end{array}$ \\
\hline 4 & $42 / M$ & Sacral & $\begin{array}{l}\text { Low back ache, urinary retention } \\
\text { ( } 1 \text { month) }\end{array}$ & Conventional Chordoma & $\begin{array}{l}\text { EBRT } 20 \text { cycles RT, } 3 \text { years } \\
\text { on follow up }\end{array}$ \\
\hline 5 & $37 / F$ & Clivus & Diplopia (3 weeks) & Chondroid chordoma & No follow up \\
\hline 6 & $50 / F$ & Sacral & $\begin{array}{l}\text { Low back ache, radiculopathy } \\
\text { ( } 4 \text { months) }\end{array}$ & Chondroid chondroma & $\begin{array}{l}\text { EBRT } 20 \text { cycles RT, } 2 \text { years } \\
\text { on follow up }\end{array}$ \\
\hline 7 & $50 / \mathrm{M}$ & Sacral & $\begin{array}{l}\text { Painful visible swelling over } \\
\text { sacral area, constipation } \\
\text { ( } 3 \text { months) }\end{array}$ & $\begin{array}{l}\text { Conventional Chordoma } \\
\text { (FNAC done) }\end{array}$ & $\begin{array}{l}\text { EBRT } 20 \text { cycles RT, } 2 \text { years } \\
\text { on follow up }\end{array}$ \\
\hline 8 & $45 / \mathrm{M}$ & Sacral & Low back ache (5 months) & Conventional Chordoma & $\begin{array}{l}\text { EBRT } 20 \text { cycles RT, } 2 \text { years } \\
\text { on follow up }\end{array}$ \\
\hline 9 & $50 / \mathrm{M}$ & Sacral & Low back ache, pain (4 months) & Conventional Chordoma & $\begin{array}{l}\text { EBRT } 20 \text { cycles RT, } 2 \text { years } \\
\text { on follow up }\end{array}$ \\
\hline 10 & $60 / \mathrm{M}$ & Lumbar & $\begin{array}{l}\text { Low back ache ( } 5 \text { months), } \\
\text { spastic paraplegia, retention of } \\
\text { urine ( } 1 \text { week) }\end{array}$ & $\begin{array}{l}\text { De-differentiated } \\
\text { chordoma with } \\
\text { metastasis to cervical } \\
\text { vertebrae }\end{array}$ & Died within 3 months \\
\hline 11 & $45 / \mathrm{M}$ & Sacral & Low back ache (6 months) & Conventional Chordoma & $\begin{array}{l}\text { EBRT } 20 \text { cycles RT, } 2 \text { years } \\
\text { on follow up }\end{array}$ \\
\hline 12 & $45 / M$ & $\begin{array}{l}\text { Sacro- } \\
\text { coccygeal }\end{array}$ & $\begin{array}{l}\text { Difficulty in walking, pain lower } \\
\text { back, radiculopathy ( } 3 \text { months) }\end{array}$ & Chondroid chordoma & $\begin{array}{l}\text { EBRT } 20 \text { cycles RT, } 2 \text { years } \\
\text { on follow up }\end{array}$ \\
\hline 13 & $53 / \mathrm{M}$ & Sacral & Low back ache ( 2 months) & Conventional Chordoma & $\begin{array}{l}\text { EBRT } 20 \text { cycles RT, } 1 \text { year on } \\
\text { follow up }\end{array}$ \\
\hline 14 & $55 \mathrm{M} /$ & Sacral & -do-(3 months) & Conventional Chordoma & $\begin{array}{l}\text { EBRT } 20 \text { cycles RT, } 1 \text { years } \\
\text { on follow up }\end{array}$ \\
\hline 15 & $60 / F$ & Sacral & do-(4 months) & Conventional Chordoma & $\begin{array}{l}\text { EBRT } 20 \text { cycles RT, } 1 \text { year on } \\
\text { follow up }\end{array}$ \\
\hline 16 & $60 / M$ & $\begin{array}{l}\text { Sacro- } \\
\text { coccygeal }\end{array}$ & $\begin{array}{l}\text { Constipation, Low back ache } \\
\text { (1 month) }\end{array}$ & Conventional Chordoma & $\begin{array}{l}\text { EBRT } 20 \text { cycles RT, } 3 \text { years } \\
\text { on follow up. Recurred } \\
\text { in } 2011 \text { re-operated and } \\
\text { subjected to RT. }\end{array}$ \\
\hline 17 & $14 / F$ & Sacral & $\begin{array}{l}\text { Constipation, difficulty in } \\
\text { walking, pain ( } 1 \text { month), } \\
\text { palpable swelling ( } 1 \text { week) }\end{array}$ & $\begin{array}{l}\text { Conventional } \\
\text { Chordoma(FNAC done) }\end{array}$ & $\begin{array}{l}\text { EBRT } 20 \text { cycles RT, } 1 \text { year on } \\
\text { follow up }\end{array}$ \\
\hline 18 & $60 / M$ & Lumbosacral & $\begin{array}{l}\text { Low back ache, difficulty in } \\
\text { walking ( } 6 \text { months) }\end{array}$ & Conventional Chordoma & $\begin{array}{l}\text { EBRT } 20 \text { cycles RT, } 6 \text { months } \\
\text { on follow up }\end{array}$ \\
\hline
\end{tabular}

Age in years. EBRT- external beam radiotherapy; $\boldsymbol{R}$ T- Radiotherapy; $\boldsymbol{M}$ - male, $\mathbf{F}$-female. 
chordoma characterized by classical vacuolated physalipharous cells floating in a pool of mucinous material arranged in lobules. There were 4 cases of chondroid chordomas showing islands of hyaline cartilage (at least $60 \%$ or more) with interspersed areas of classical morphology. One case showed cells with histological atypia, areas of necrosis and high proliferative activity ( $>5 \%$ cells were positive for $\mathrm{K} 1-67$ ). This was classified as dedifferentiated chordoma. In our analysis of 18 cases, there were 13 cases of conventional chordoma, 4 cases of chondroid chordoma and 1 case of dedifferentiation. Immunohistochemistry was done showed cells to be strongly positive for S-100 and cytokeratin (Figure 2A-C).

\section{Adjuvant Therapy}

All patients were subjected to Cobalt- 60 based external beam radiotherapy of $60 \mathrm{cGys}$ irrespective of the grade of excision: total or subtotal.

\section{Follow-Up}

The follow-up varied from 3 months to 6 years. The patients followed up at our centre were planned to undergo MRI/ CT scan of the primary site every 6- months for the first two years, every year for the following 3 years. A chest X-ray/CT scan and abdomen pelvis US/CT scan were performed every 6 months while a bone scan was planned every 1 year. One patient of spinal dedifferentiated chordoma died 3-months after the surgery. We noted recurrence in one patient with a sacrococcygeal chordoma. The recurrence took place 4-years after the first surgery. This patient was re-operated and subtotal excision only could be done as the recurrence was involving the pelvic viscera also and hence a repeat radiotherapy was also given. All other patients are alive with minimal to no neurodeficit and are able to perform activities of daily life independently. Kaplan-Meier survival analysis showed that the gender and the site of the tumor had no bearing on the outcome however tumors have a poor prognosis (Figure 3A-C). Histopathologically, most chordomas in our study were of a conventional variety (72\%) and we had 4 cases (22\%) of chondroid chordoma which is supposed to have a better prognosis.

\section{DISCUSSION}

Chordoma is a relatively slow-growing invasive neoplasm that destroys and replaces the bone in which it develops and sometimes causes distant metastasis. It develops from the embryonic remnants of the notochord which undergo neoplastic transformation and develops most commonly in the axial skeleton at the base of the skull and sacrococcygeal region, infrequently in other vertebrae and rarely extranotochordally (12).

Because of the rarity of this tumor, there are only a few published series on chordoma. This tumor usually occurs in the middle-aged population. The median age has been reported to vary from $59-62$ years $(1,11)$. In our series these tumors occurred at a relatively younger age than reported in the literature (26). We had a median age of 46.72 years in our patients. The tumor has a predilection for males $(1,11,26)$. We observed a 7:2 ratio in favor of males. Although sex is not thought to be of prognostic value in chordomas, it has been suggested that female sex is an independent predictor of shortened survival in skull base chordomas (20). We in our series did not notice such a finding.

The duration of symptoms before diagnosis is long with a median duration of 12 months $(4,10)$ but the duration of symptoms was relatively short, i.e., 11.8 weeks (range 2-24 weeks) in our study. The sacrum is the commonest site hence duration of low back ache before the patients present to the physician is long compared to when the clivus is involved which may present with diplopia because of involvement of the abducent nerve and alerts the patient early. This was obvious in our series also where the tumors involving the clivus presented within one week while as sacral chordomas reported within 1-6 months. Pain was the predominant symptom in our series. In a study on 27 patients with sacral chordoma in a 40 year period, all but one of the patients presented with back pain and lower extremity pain and seventeen patients presented with autonomic dysfunction as evidenced by sphincter or sexual dysfunction (26).
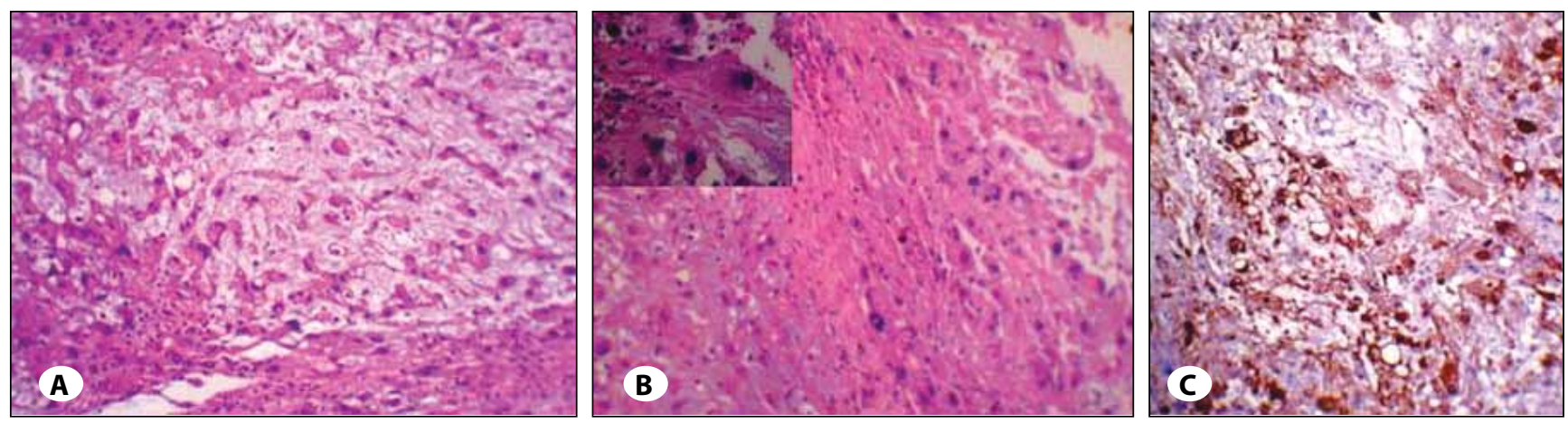

Figure 2: (A) Photomicrograph showing classical chordoma with physaliphorous cells in a mucoid matrix (Haematoxylin\&Eosin x 20), (B). Photomicrograph showing a pleomorphic cells of a de-differentiated chordoma (Haematoxylin\&Eosin x20). Inset: a pleomorphic physaliphorous cell with increased nuclear cytoplasmic ratio (Haematoxylin\&Eosin x 40). (C) Photomicrograph showing chordoma with positivity for S-100 (Immunostain x 20). 


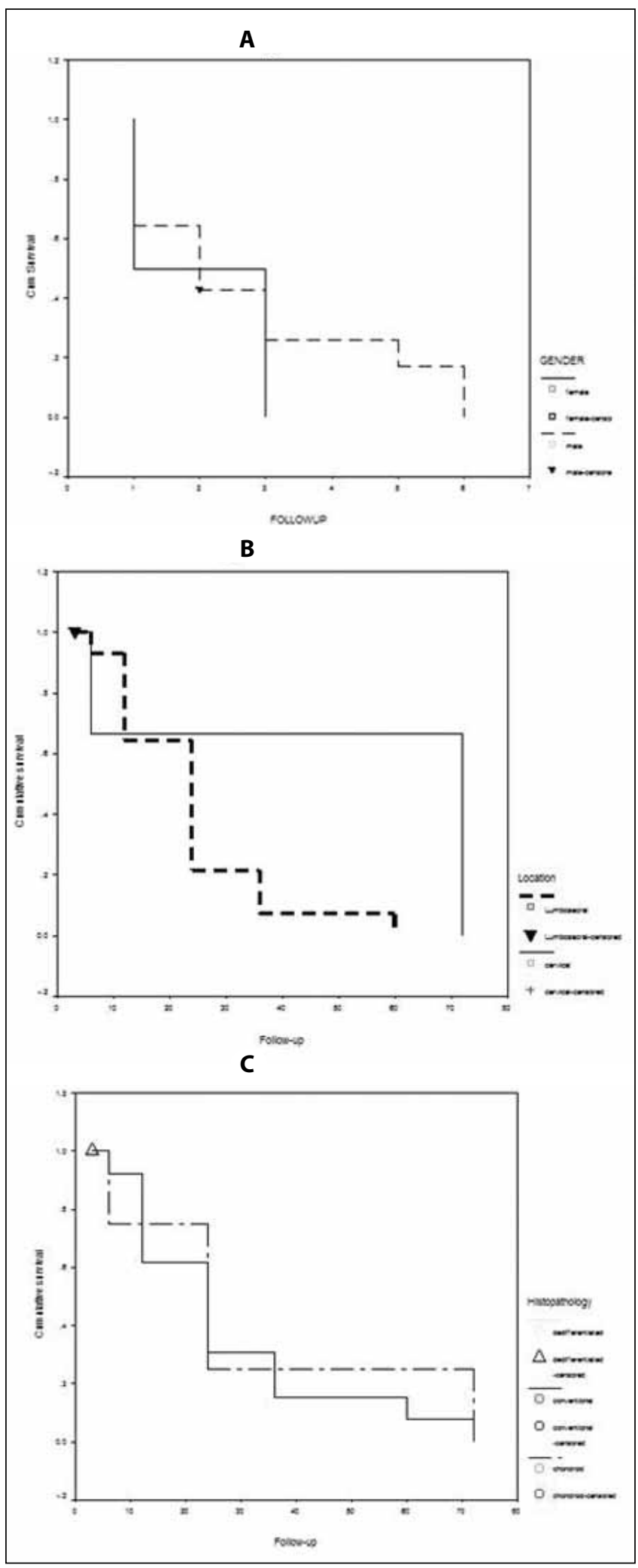

Figure 3: Kaplan-Meier survival analysis shows the effects of gender (A), site of tumor (B) and histopathology (C). There was no correlation between survival and gender or site of tumor. There was a trend of correlation between survival and histopathological subtype which however was not statistically significant.
CT scan reveals a midline sacral lytic lesion. Calcification is seen in $50-70 \%$ tumors. Often there is a large presacral mass. MRI reveals the mass to be hypo and hyperintense on T1- and T2- weighted sequences respectively. Isotope scan shows a normal or decreased uptake. The extent of the tumor is best seen on MRI scan. On imaging the differential diagnosis includes other primary bone tumors, metastasis, multiple myeloma and lymphoma. All the metastatic lesions on MRI will be hypointense on T1-weighted and hyperintense on T2weighted sequence. Sacral chordomas and chondrosarcomas have specks of calcifications. Multiple myeloma involving the bone shares the same characteristics on MRI imaging. MRI is better in delineating the soft tissue involvement and $C T$ is sensitive in documenting whether the lesion is lytic or sclerotic and also in detecting the calcifications (17). We noticed calcification in $50 \%$ cases and MRI showed the classical hypo- and hyperintensity of the lesions on T1- and T2-weighted sequences respectively. Isotope scan was not done in any of our patients.

In a large study of spinal chordomas, $48 \%$ involved the sacrococcygeal region, $38.5 \%$ occurred at the skull base and the remainder along the mobile spine (5). In a series of 25 patients with chordoma the site of origin of chordoma was the sacrum in 11 patients, spine in 13 patients and skull base in one patient (11). In the Danish national study, based on the data of 37 patients in 25 years, the tumors were located in the sacrococcygeal region in $68 \%$, spheno-occipital region in $16 \%$ and vertebrae in $16 \%$ (1). In our study, the majority (72\%) tumors were located in the sacrococcygeal region, $11 \%$ in the clivus, $5 \%$ in upper cervical region, $5 \%$ in the lumbar region and $5 \%$ in the lumbosacral region.

The primary modality of treatment in chordomas is surgery. The extent of resection is dictated by the site of the lesion (23). Tumors involving the sacrum below S- 2 without involvement of sacroiliac joint can be managed by total resection of the tumor without any compromise of the major neurological functions. If total sacrectomy is done for high sacral tumors, instrumentation and fusion is needed to provide mechanical support to spine (13). Tumors of the clivus are best managed by subtotal decompression and radiotherapy. These present a major challenge to the neurosurgeon because gross total removal of the tumor with preservation of neural and vascular structures is difficult (20). High cervical tumors can be managed by trans-oral decompression and posterior stabilization of the spine (2).

The extent of initial surgical resection plays an important role in the subsequent surgical outcome of sacral chordomas. Complete and radical resection contributes to high local control rate and the prolongation of disease-free survival (26). Looking at the resectability of sacral chordomas, most series have reported difficulty in obtaining wide surgical margins and the expected local failure rate in case of a marginal resection is in excess of $70 \%(13,21)$. Local recurrence is closely related to surgical margins $(16,22,26)$. York JE et al reported that local control rates were $60-80 \%$ in cases who 
underwent total excision as compared with rates of $25-50 \%$ in subtotal resection and demonstrated a statistically significant difference in the time from surgery to local recurrence between patients who underwent radical resection and those who underwent subtotal resection (26). The primary modality of treatment in our patients was surgery. Total excision of the tumor along with the resection of the lower sacrum and coccyx was done in 6 patients in whom we obtained wide surgical margins. Of the other nine patients with sacral chordoma in whom subtotal resection was done with postoperative radiotherapy, only one of our patients had recurrence after two years.

Beigh $P$ et al (3) reported inadequate surgical margin to be an independent prognostic factor for tumor-related death. Although intralesional resection is not a preferred treatment option because of the worse control of tumor and the higher relative risk of reduced survival associated with this procedure, the anatomic characteristics of tumor location and spreading not infrequently result in patients having unresectable tumors or tumors that can only be incompletely resected. Intensive radical resections have been associated with greater neurological deficits (25). Total sacrectomy may sometimes warrant a colostomy or a permanent urinary diversion (9). In our patients with chordomas involving the sacrum above the level of S1S2, partial removal of the tumor with postoperative radiotherapy was highly effective. The surgery was not staged as has been done in some series (11).

Surgery with postoperative radiotherapy was very effective in our patients and following points are worthy of note:

1. None of our patients had wound dehiscence or postoperative wound infection.

2. None of our patients required a colostomy or a permanent catheter.

3. With surgical intervention, the symptoms of pain, urinary dysfunction and bowel dysfunction improved considerably.

4. All our patients were ambulatory and showed improvement in the neurological deficits after surgery.

5. The surgery in all patients was performed as a singlestage procedure.

6. The outcome was good even in patients in whom the wide resection margins were not obtained and were subjected to post operative radiotherapy after subtotal resection.

We recommend that adequate surgery with wide margins should be performed in centers having technical expertise. The extension of margins believed to be a very important prognostic factor and being correlated with the incidence of local relapses and overall survival in many series (7) did not alter prognosis considerably in our series.

\section{REFERENCES}

1. Akmal S, Nielsen OS, Jurik AG, Keller J, Weeth ER, Lund B, Jensen OM: A retrospective clinicopathological study of 37 patients with chordoma: A Danish national series. Sarcoma 1:161-165, 1997

2. Austin MB, Mill SE: Neoplasms and neoplasm-like lesions involving the skull base. Ear, Nose Throat J 65 (2):25-52, 1986

3. Beigh P, Kindblom LG, Gunterberg B, Remotti F, Ryd W, Meiskindblom JM: Prognostic factors in chordoma of the sacrum and mobile spine; a study of 39 patients. Cancer (Phila) 88:2122-2134, 2000

4. Bethke KP, Neifelt JP, Lawrence JRW: Diagnosis and management of sacroccygeal chordoma. J Surg Oncol 48:232-238, 1991

5. Bjornson J, Wold LE, Enersold MJ, Lawa ER: Chordoma of the mobile spine: A clinicopathologic analysis of 40 patients. Cancer 71:735-740, 1993

6. Casali PG, Stacchiotti S, Sangali C, Olmi P, Gronchi A:Chordoma Curr Opin Oncol 19:367-370, 2007

7. Cheng EY, Ozerdemoglu RA, Transfeldt EE, Thompson RC Jr: Lumbosacral chordoma. Prognostic factors and treatment. Spine 24:1639-1645, 2000

8. Chugh R, Tawbi H, Lucas DR, Biermann JS, Schuetze SM, Baker LH: Chordoma: The non-sarcoma primary bone tumor. Oncologist 12(11):1344-1350, 2007

9. Doita M, Harada T, Iguch T, Sumi M, Sha H, Yoshiya S, Kurosaka M: Total sacrectomy and reconstruction for sacral tumors. Spine 28:296-301, 2003

10. Eriksson B, Gunterberg B, Kindblom LG: Chordoma: A clinicopathologic and prognostic study of a Swedish National series. Acta Orthop Scand 52:49-58, 1981

11. Ferraresi V, Nuzzo C, Zoccali C, Marandino F, Virdiri A, Salducca N, Zeuli M, Giannarelli, et al: Chordoma: Clinical characteristics, management and prognosis of a case series of 25 patients. BMC Cancer 10,22:1-10, 2010

12. Fichardt T, de Villers PC: Chordoma. S Afr Med J 48:383-390, 1974

13. Fuchs B, Dicky ID, Yaszemski MJ, Inwards CY, Sim FH: Operative management of sacral chordoma. J Bone Joint Surg 87: 2211-2216, 2005

14. Higinbotham NL, Philips RF, Farr HW, Husta HO: Chordoma thirty-five year study at Memorial Hospital. Cancer 20(11):1841-1850, 1967

15. Jemal A, Siegel R, Ward E, Murray T, Xu J, Thun MJ: Cancer statistics-2007. CA Cancer J Clin 57(1):43-66, 2007

16. Kaiser TE, Pritchard DJ, Unni KK: Clinicopathologic study of sacrococcygeal chordoma. Cancer 53:2574-2578, 1984

17. Llauger J, Palmer J, Amores S, Bague S, Camins A: Primary tumors of the sacrum: Diagnostic imaging. AJR 174:417-424, 2000 
18. Magrini SM, Papi MG, Marletta F, Tomaselli S, Cellai E, Mungai V, Biti G: Chordoma natural history, treatment and prognosis. The Florence Radiotherapy Department experience (19561990) and a critical review of the literature. Acta Oncol 31:845-851, 1992

19. Fletcher CD, Unni K, Mertens F: Pathology and genetics of tumors of soft tissue and bone. In Mira JM, Della Roccac, Nelson SD, Mertens F (eds), Chordoma. Lyon: IARC Press, 2002:316-317

20. O'Connell JX, Renard LG, Liebsch NJ, Efird JT, Munzenrider JE, Rosenberg A: Base of skull chordoma: A correlative study of histologic and clinical features of 62 cases. Cancer 74: 2261-2267, 1994

21. Osaka S, Kodoh O, Sugita H, Osaka E, Yoshida Y, Ryu J: Clinical significance of a wide excision policy for sacrococcygeal chordoma. J Cancer Res Clin Oncol 132:213-218, 2006
22. Ozaki T, Hillmann A, Winkelmann W: Surgical treatment of sacrococcygeal chordoma. J Surg Oncol 64:274-279, 1997

23. Sundaresan N, Huvos AG, Kral G, Lane JM, Brennan M: Surgical treatment of spinal chordomas. Arch Surg 122:1479-1482, 1987

24. Vujovic S, Henderson S, Presneau N,Odell E, Jacques TS, Tiraboscor R, Boshoff C, Flangan AM: Brachyury, a crucial regulator of notochordal development is a novel biomarker for chordoma. J Pathol 209:157-165, 2006

25. Yonemoto T, Tatezaki S, Takenouchi T, Ishii T, Satoh T, Moriya $\mathrm{H}$ : The surgical management of sacrococcygeal chordoma. Cancer (Phila) 85:878-883, 1999

26. York JE, Kaczaraj A, Abi-Said D: Sacral chordoma: 40 year experience at a major cancer centre. Neurosurgery 44:74-79, 1999 